\title{
Emerging applications for OCT in the head and neck
}

\author{
Marc Rubinstein*, Jason Kim, William Armstrong, Hamid Djalilian, Zhongping Chen, Brian Wong \\ From 2nd Scientific Meeting of the Head and Neck Optical Diagnostics Society \\ San Francisco, CA, USA. 23-24 January 2010
}

\section{Objectives}

To describe the current and promising new applications of the Optical Coherence Tomography (OCT) as a helpful tool when imaging the different sites in the head and neck. Using the OCT Niris system, which is the first commercially available OCT device for applications outside the field of ophthalmology.

\section{Methods}

We obtained OCT images of normal, benign, premalignant and malignant lesions in different areas of the head and neck. The OCT imaging system has a tissue penetration depth of approximately $1-2 \mathrm{~mm}$, a scanning range of $2 \mathrm{~mm}$ and a spatial depth resolution of approximately $10-20 \mu \mathrm{m}$. Imaging was performed using a flexible probe in two different situations, the outpatient clinic and the operating room.

\section{Results}

High-resolution cross-sectional images from the larynx were obtained with the patient awake, without the need of general anesthesia. The OCT probe was inserted through the nasal cavity and placed in slightly contact with the laryngeal tissue, under direct visualization with a flexible fiberoptic. Images of other sites, such as the oral cavity, nasal cavity, and ears were also obtained in various settings.

\section{Conclusions}

This system is non invasive and easy to incorporate into the operating room as well as to the outpatient clinic. It requires minimal set-up and requires only one person to operate the system. OCT has the distinctive capability to obtain high-resolution images, where the microanatomy of different sites can be observed. OCT technology

\footnotetext{
Beckman Laser Institute and Medical Clinic, University of California Irvine,
} Irvine, California, USA has the potential to offer a quick, efficient and reliable imaging method to help the surgeon not only in the operating room but also in the clinical setting to guide surgical biopsies and aid in the decision making of different head and neck pathologies, especially those arising form the larynx.

Published: 29 October 2010

doi:10.1186/1758-3284-2-S1-041

Cite this article as: Rubinstein et al:: Emerging applications for OCT in the head and neck. Head \& Neck Oncology 2010 2(Suppl 1):O41.
Submit your next manuscript to BioMed Central and take full advantage of:

- Convenient online submission

- Thorough peer review

- No space constraints or color figure charges

- Immediate publication on acceptance

- Inclusion in PubMed, CAS, Scopus and Google Scholar

- Research which is freely available for redistribution

Submit your manuscript at www.biomedcentral.com/submit
C Biomed Central 